\title{
Long-term elevation of $\beta$-hydroxybutyrate in dairy cows through infusion: Effects on feed intake, milk production, and metabolism
}

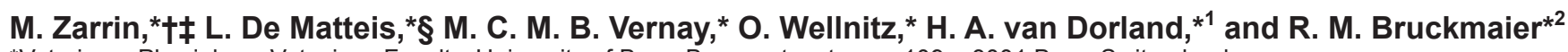 \\ *Veterinary Physiology, Vetsuisse Faculty, University of Bern, Bremgartenstrasse 109a, 3001 Bern, Switzerland \\ †Department of Animal Science, Agriculture Faculty, Yasouj University, Student Street, 75918-74831, Yasouj, I. R. Iran \\ ‡Graduate School for Cellular and Biomedical Sciences, University of Bern, Freiestrasse 1, 3012 Bern, Switzerland \\ §Istituto di Zootecnica, Facoltà di Agraria, Università Cattolica del Sacro Cuore, I-29100 Piacenza, Italy
}

\begin{abstract}
Elevation of ketone bodies in dairy cows frequently occurs in early lactation, usually concomitantly with a lack of energy and glucose. The objective of this study was to induce an elevated plasma $\beta$-hydroxybutyrate (BHBA) concentration over $48 \mathrm{~h}$ in mid-lactating dairy cows (i.e., during a period of positive energy balance and normal glucose plasma concentrations). Effects of BHBA infusion on feed intake, metabolism, and performance were investigated. Thirteen cows were randomly assigned to 1 of 2 infusion groups, including an intravenous infusion with Na-DL- $\beta$-OH-butyrate $(1.7 \mathrm{~mol} / \mathrm{L})$ to achieve a plasma concentration of 1.5 to $2.0 \mathrm{mmol} / \mathrm{L}$ of BHBA (HyperB; $\mathrm{n}=5$ ), or an infusion of $0.9 \%$ saline solution (control; $\mathrm{n}=8$ ). Blood was sampled before and hourly during the $48 \mathrm{~h}$ of infusion. In the liver, mRNA transcripts related to gluconeogenesis (pyruvate carboxylase, glucose 6-phosphatase, mitochondrial phosphoenolpyruvate carboxykinase), phosphofructokinase, pyruvate dehydrogenase complex, and fatty acid synthesis (acetyl-coenzyme A carboxylase, fatty acid synthase) were measured by real-time PCR. Glyceraldehyde-3-phosphate dehydrogenase and ubiquitin were used as housekeeping genes. Changes (difference between before and after 48-h infusion) during the infusion period were evaluated by ANOVA with treatment as fixed effect, and area under the curve of variables was calculated on the second day of experiment. The plasma BHBA concentration in HyperB cows was $1.74 \pm 0.02 \mathrm{mmol} / \mathrm{L}$ (mean $\pm \mathrm{SE}$ ) compared with $0.59 \pm 0.02 \mathrm{mmol} / \mathrm{L}$ for control cows. The change in feed intake, milk yield, and energy corrected milk did not differ between the 2 experimental groups. Infusion of BHBA reduced the plasma glucose concentration $(3.47 \pm 0.11 \mathrm{mmol} / \mathrm{L})$ in HyperB compared with
\end{abstract}

Received October 3, 2012.

Accepted January 27, 2013.

${ }^{1}$ Present address: School of Agricultural, Forest and Food Sciences, Bern University of Applied Sciences, Laenggasse 85, 3052 Zollikofen, Switzerland.

${ }^{2}$ Corresponding author: rupert.bruckmaier@vetsuisse.unibe.ch control cows $(4.11 \pm 0.08 \mathrm{mmol} / \mathrm{L})$. Plasma glucagon concentration in HyperB was lower than the control group. All other variables measured in plasma were not affected by treatment. In the liver, changes in mRNA abundance for the selected genes were similar between 2 groups. Results demonstrate that intravenous infusion of BHBA decreased plasma glucose concentration in dairy cows, but this decrease could not be explained by alterations in insulin concentrations or key enzymes related to gluconeogenesis. Declined glucose concentration is likely functionally related to decreased plasma glucagon concentration.

Key words: ketone bodies, glucose, $\beta$-hydroxybutyrate, metabolism

\section{INTRODUCTION}

High-yielding dairy cows need a lot of energy and nutrients for maintenance and milk synthesis during peak lactation, in particular. Despite increased feed intake in early lactation (Agenäs et al., 2003), after the periparturient nadir this adaptation cannot cover the requirements during this period. Typical metabolic changes during this period of negative energy balance are low plasma concentrations of glucose and high concentrations of plasma NEFA, as well as a subsequent elevation of ketone bodies (van Dorland et al., 2009; Gross et al., 2011). Although ketone bodies can be used as an alternative fuel for some tissues, such as brain and heart (Laffel, 1999; Veech, 2004), kidney (Weidemann and Krebs, 1969), skeletal muscles (Ruderman and Goodman, 1973) and lactating mammary glands (Shaw, 1943), the utilization of ketone bodies is limited. Unused ketone bodies concentration increase tremendously in blood (Duffield et al., 2009). This elevation of ketone bodies in blood causes reduced feed intake and increases the risk of clinical ketosis, displaced abomasums, metritis, and subsequent decrease of milk production (Duffield et al., 2009). The most used method to detect subclinical ketosis is the measurement of BHBA in serum or plasma (Duffield, 2000; Herdt, 2000); in ruminants, BHBA is the major ketone body found in 
circulation (Bergman, 1971). Ospina et al. (2010) suggested a threshold value of $1,200 \mu \mathrm{mol} / \mathrm{L}$ to distinguish between normal cows and subclinical ketotic cows.

Subcutaneous BHBA infusion in rats (Moore et al., 1976; Langhans et al., 1983), intraperitoneal BHBA infusion in goats (Rossi et al., 2000), and intracerebroventricular BHBA infusion in dairy cows (Kuhla et al., 2011) led to inhibited feed intake in these animals. Intravenous BHBA infusion led to decreased plasma concentration of glucose in dogs (Madison et al., 1964), pigs (Müller et al., 1984), and ewes (Schlumbohm and Harmeyer, 2003, 2004). The reason for declined glucose during the infusion of BHBA remains unclear, but those authors suggested that infusion of BHBA induced hypoglycemia through direct or indirect inhibition of gluconeogenesis, or by a change in the insulin concentration in pig and sheep (Müller et al., 1984; Schlumbohm and Harmeyer, 2004). This mechanism has not yet been investigated in dairy cows. Our objective was to induce an elevated plasma BHBA concentration over $48 \mathrm{~h}$ and to investigate its effects on feed intake, performance, and metabolism in the dairy cow. More specifically, this study was carried out to confirm that in the dairy cows, as in sheep and pigs, elevated plasma BHBA concentration affects plasma glucose concentration, and to investigate the underlying mechanisms.

\section{MATERIALS AND METHODS}

\section{Animals and Management}

The current trial followed the guidelines of Swiss Law on Animal Protection permitted by the Committee of Animal Experiments of the Canton Fribourg, Switzerland. The study was carried out with 13 diestrus Holstein dairy cows with a parity of $3.5 \pm 0.10$ at $28 \pm 0.3$ (mean $\pm \mathrm{SD}$ ) wk in milk. Cows in later lactation were selected to allow the investigation of the specific effect of BHBA infusion without influences of the characteristic endocrine and metabolic changes during the transition period. The cows were healthy at the start of the experiment, which was confirmed by a routine blood glutaraldehyde coagulation test (Sandholm, 1976) and by measuring milk SCC (DeLaval cell counter DCC, DeLaval International AB, Tumba, Sweden), which had to be less than 150,000 cells $/ \mathrm{mL}$ in all 4 quarters.

Two weeks before the start of the experiment, animals were allowed to adapt to tiestall housing and to the experimental feeding conditions. Animals were fed ad libitum with hay. In addition, cows were fed a protein- and energy-rich concentrate (barley 23.5\%, oats $14.0 \%$, wheat bran $20.0 \%$, expeller soybean $17.0 \%$, linseed meal $15.0 \%$, salt livestock $0.6 \%$, carbonate of lime $2.2 \%$, kaf premix $0.4 \%$, molasses $4.0 \%$, and alikon
$3.0 \%$ ) twice daily according to each cow's individual extra energy requirement for milk production, and $50 \mathrm{~g}$ of minerals once daily. Water was available ad libitum. Milking was performed twice daily at 0530 and $1600 \mathrm{~h}$.

\section{Experimental Design and Treatments}

The 13 cows were randomly assigned to one of 2 infusion treatments. The treatments included (1) an infusion with BHBA (HyperB; $\mathrm{n}=5$ ) to obtain a plasma BHBA concentration between 1.5 to 2.0 $\mathrm{mmol} / \mathrm{L}$ and $(2)$ an infusion with a $0.9 \%$ saline solution $(\mathrm{NaCl}, 20 \mathrm{~mL} / \mathrm{h}$; control; $\mathrm{n}=8)$. One day before the infusions started, cows were fitted with indwelling intravenous catheters (Cavafix Certo Splittocan, B. Braun Melsungen AG, Melsungen, Germany) with a length of $32 \mathrm{~cm}$ and a diameter of 16 gauge in both jugular veins. The infusions through one of the catheters started at $0900 \mathrm{~h}$ and continued until $0900 \mathrm{~h}$ two days later. The initial infusion rate $(8.5 \pm 0.6 \mu \mathrm{mol} / \mathrm{kg}$ per min) was determined on the basis of BW of each animal and the molarity of the solution was followed by instant continued adjustments throughout the 48 $\mathrm{h}$ to maintain a plasma BHBA concentration between 1.5 to $2.0 \mathrm{mmol} / \mathrm{L}$ by a peristaltic pump (Perpex Jubile pump, H. J. Guldener, Zürich, Switzerland). During the first $2 \mathrm{~h}$ of BHBA infusion, the blood samples were taken every 15 min to measure the plasma BHBA concentration and adjust the BHBA infusion rate to reach the plasma BHBA concentration between 1.5 and $2.0 \mathrm{mmol} / \mathrm{L}$. The control cows were treated with $0.9 \%$ saline solution at an infusion rate of $20 \mathrm{~mL} / \mathrm{h}$ administered using an automatic pump (Perfuser, B. Braun Melsungen AG).

\section{Preparation of the BHBA Solution}

To achieve a 1.7 $M$ BHBA solution, $279.053 \mathrm{~g}$ of DLBHBA acid sodium salt (H6501, Sigma-Aldrich, Basel, Switzerland) was dissolved in bi-distilled water to reach an amount of $1.0 \mathrm{~L}$, followed by homogenization using a rotor mixer for 10 to $20 \mathrm{~min}$. The $\mathrm{pH}$ of the solution was adjusted with $\mathrm{HCl}$ to 7.4 and sterilized at $100 \mathrm{kPa}$ and $131^{\circ} \mathrm{C}$ for $50 \mathrm{~min}$. The solution was filtered through a $0.2-\mu \mathrm{m}$ filter (Millipore Express Plus Membrane 45 $\mathrm{mm}$, Millipore, Billerica, MA) and stored at $4^{\circ} \mathrm{C}$ until infusion.

\section{Data Collection and Sampling}

Feed and Milk Samples. The individual intake of hay was recorded daily for each cow by weighing the amount given and subtracting it by the remainder of hay found the next morning. The milk yield was record- 
ed for each cow individually at every milking during the adaptation and experimental period. Proportional milk samples were taken during milking in the afternoon and in the morning before the start of the experimental infusions. The milk sampling was repeated in the afternoon of $\mathrm{d} 2$ (32 h after the start of infusion), and at the morning milking at the end of experiment.

Blood Samples. One week before the experiment, and immediately before the start of the experimental infusions on d 1, reference blood samples of each cow were taken from a jugular vein via vacuum tubes containing tri-potassium-EDTA at $0730 \mathrm{~h}$, after milking and before feeding. The tubes were kept on wet ice until they were centrifuged for $20 \mathrm{~min}$ at $3,000 \times g$ and the plasma was obtained. Until the samples were analyzed for concentrations and activities of plasma variables, the plasma was frozen at $-20^{\circ} \mathrm{C}$. After analysis, the mean value of these samples was calculated and used as the reference concentration in the statistical evaluation. During the experimental infusions, blood samples were obtained from the contralateral jugular catheter, which was not used for the infusion, by using tubes containing tri-potassium-EDTA. The collected blood samples were partly analyzed immediately for BHBA concentration (described under Laboratory Procedures) as a basis for adjustments of the infusion rate, or were handled similar to the reference samples.

Liver Biopsies. One week before the infusions and $48 \mathrm{~h}$ after the start of the infusions, following the blood sampling at around $0800 \mathrm{~h}$, a liver biopsy was taken. Liver tissue (60-100 mg) was obtained under local anesthesia with $10 \mathrm{~mL}$ of Lidocain 2\% (Streuli Pharma AG, Uznach, Switzerland) by blind liver puncture with a 14-gauge and $150 \mathrm{~mm}$ or $200 \mathrm{~mm}$ long biopsy needle (Tru-Cut, Provet AG, Lyssach, Switzerland). The samples were placed directly into RNA stabilization reagent (RNAlater, Ambion, Applied Biosysthems, Austin, TX), kept at $5^{\circ} \mathrm{C}$ for $24 \mathrm{~h}$, and then stored at $-80^{\circ} \mathrm{C}$ until RNA extraction.

\section{Laboratory Procedures}

Feed and Milk. The nutritional composition of hay (DM content, $890 \mathrm{~g} / \mathrm{kg}$ of fresh matter; on DM basis, consisting of $153 \mathrm{~g}$ of $\mathrm{CP} / \mathrm{kg}, 235.0 \mathrm{~g}$ of crude fiber $/ \mathrm{kg}$, and 5.7 MJ of $\mathrm{NE}_{\mathrm{L}} / \mathrm{kg}$ ) and concentrate (DM content, $881 \mathrm{~g} / \mathrm{kg}$ of fresh matter; on DM basis, consisting of $217 \mathrm{~g}$ of $\mathrm{CP} / \mathrm{kg}, 73.9 \mathrm{~g}$ of crude fiber $/ \mathrm{kg}$, and $7.6 \mathrm{MJ}$ of $\mathrm{NE}_{\mathrm{L}} / \mathrm{kg}$ ) were determined by using routine analyses as described by van Dorland et al. (2009). The nutritive energy balance was calculated as the difference between the energy intake, and the energy output $\left[\mathrm{NE}_{\mathrm{L}}\right.$, requirements for maintenance and milk production, determined from tabulated values and recommended equations according as to van Dorland et al. (2009)].

Milk samples were analyzed at the laboratory of the Holstein Association of Switzerland (Grangeneuve, Switzerland) for content of fat, protein, lactose, and urea (CombiFoss 6000, Gerber Instrument AG, Effretikon, Switzerland). The ECM was calculated based on Sjaunja et al. (1991), using the formula ECM $(\mathrm{kg} / \mathrm{d})=$ $\{[0.038 \times$ Fat $(\mathrm{g} / \mathrm{kg})+0.024 \times$ Protein $(\mathrm{g} / \mathrm{kg})+0.017$ $\times$ Lactose $(\mathrm{g} / \mathrm{kg})] \times$ Milk Yield $[\mathrm{kg} / \mathrm{d}]\} / 3.14$.

Blood Plasma. Plasma metabolites were measured enzymatically with an automated analyzer (Cobas Mira 2, Hoffmann-La Roche, Basel, Switzerland) by the use of commercial kits as described by van Dorland et al. (2009) and Kreipe et al. (2011). Plasma insulin and IGF-1 were measured by RIA as described by Vicari et al. (2008), and total cortisol was measured by RIA as described by Blum et al. (1985). Plasma glucagon concentration was measured by using a RIA kit (cat. \#GL-32K, Millipore, Zug, Switzerland).

Liver Tissue. Total mRNA was extracted from liver samples using peqGOLD TriFast (PEQLAB Biotechnologie GmbH, Erlangen, Germany) according to the manufacturer's protocol, and afterward quantity and purity were determined by absorbance at 260 and 280 nm using a NanoDrop ND-2000 spectrophotometer (NanoDrop Technologies Inc., Wilmington, DE). Subsequently, $1 \mu \mathrm{g}$ of total mRNA was reverse transcribed with 200 U of Moloney Murine Leukemia Virus Reverse Transcriptase RNAase H Minus, Point Mutant (Promega Corp., Madison, WI) using 100 pmol of random hexamer primers (Invitrogen, Leek, the Netherlands). A master mix was prepared containing the following components: $0.8 \mu \mathrm{L}$ of PCR water, $1.0 \mu \mathrm{L}$ of forward primer $(5 \mathrm{pmol}), 1.0 \mu \mathrm{L}$ of reverse primer $(5 \mathrm{pmol}), 5.2$ $\mu \mathrm{L}$ of $2 \times$ SensiMix plus SYBR-Green (1 $\mathrm{mM} \mathrm{MgCl} 2)$. The selected and measured genes encoding for hepatic enzymes involved in gluconeogenesis, glycolysis, FA oxidation, citrate synthase, FA and triglyceride synthesis, cholesterol synthesis, pyruvate dehydrogenase complex, and ketogensis are shown in Table 1. The primer sequences for pyruvate carboxylase (PC) and mitochondrial phosphoenolpyruvate carboxykinase were according to Hammon et al. (2003); FA synthase, acyl-CoA synthetase long-chain, carnitine palmitoyltransferase $1 \mathrm{~A}$, and citrate synthase were according to van Dorland et al. (2009); acetyl-CoA carboxylase (ACoAC), carnitine palmitoyltransferase 2, glucose6-phosphatase, and 3-hydroxyl-3-methylglutaryl-CoA synthase 1 (HMGCS1) were according to Graber et al. (2010). Lactate dehydrogenase A, lactate dehydrogenase B, phosphofructokinase-liver, dihydrolipoamide branched chain transacylase E2, dihydrolipoamide 
dehydrogenase, pyruvatedehydrogenase (lipomide) $\alpha$ 1 , glucagon receptor, glycogen synthase 2 , and protein kinase AMP-activated $\alpha 1$ (PRKAA1) primers were designed to amplify cDNA.
The PCR quantification was performed by using a Rotor-Gene 6000 (Corbett Research, Sydney, Australia), using the software version 1.7.40. Fluorescence take-off was calculated with the threshold program op-

Table 1. Polymerase chain reaction primer information (for $=$ forward, rev $=$ reverse), annealing temperature, and the PCR product length

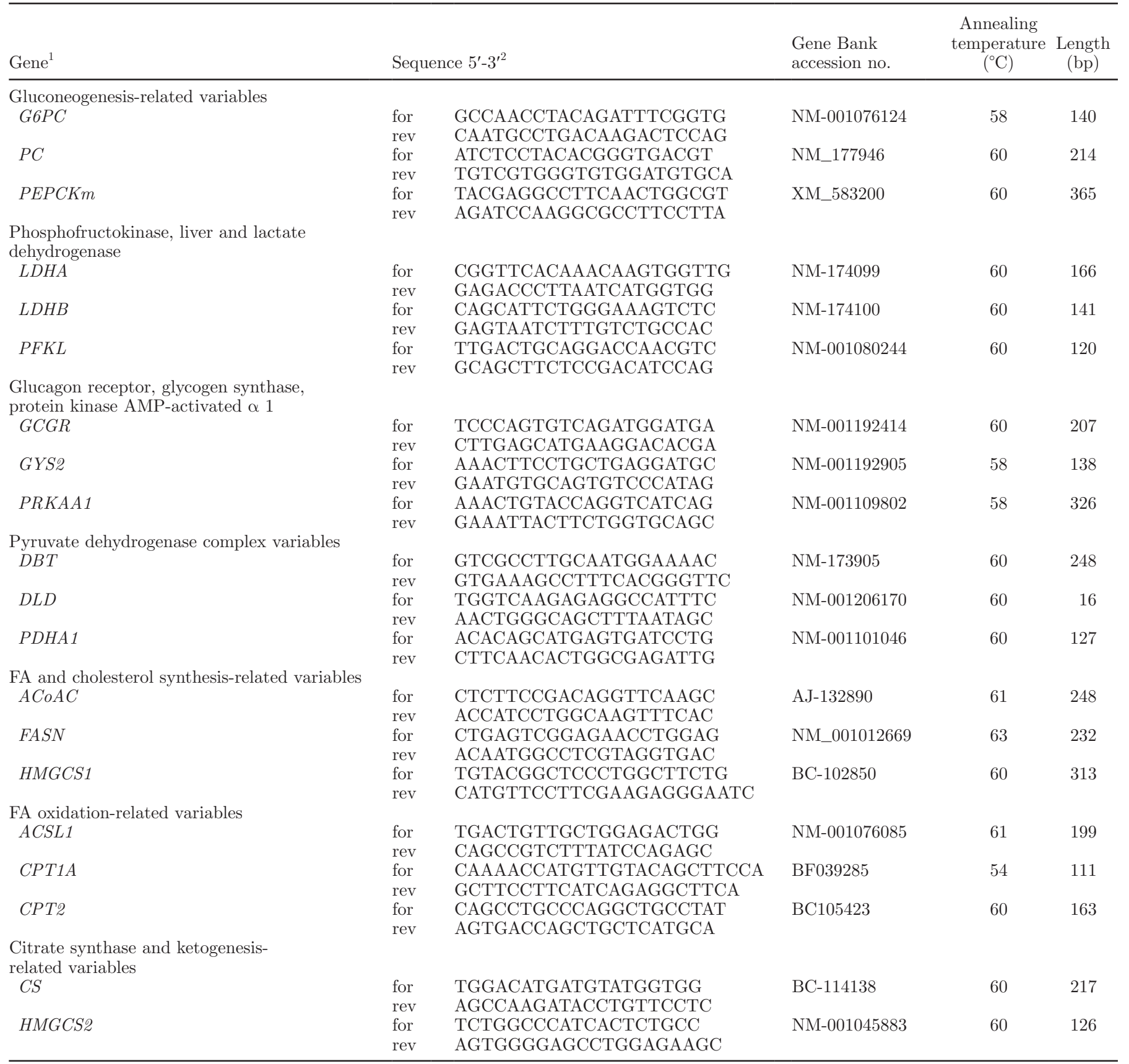

${ }^{1} \mathrm{G} 6 \mathrm{PC}=$ glucose-6-phosphatase $\mathrm{PC}=$ pyruvate carboxylase; $\mathrm{PEPCKm}=$ mitochondrial phosphoenolpyruvate carboxykinase; $\mathrm{LDHA}=$ lac tate dehydrogenase A; LDHB = lactate dehydrogenase B; PFKL = phosphofructokinase liver; GCGR = glucagon receptor; GYS2 = glycogen synthase 2; PPKA1 = protein kinase AMP-activated $\alpha 1$; DBT = dihydrolipoamide branched chain transacylase E2; DLD = dihydrolipoamide dehydrogenase; PDHA1 = pyruvatedehydrogenase (lipomide) $\alpha$ 1; ACoAC = acetyl-CoA carboxylase; FASN = fatty acid synthase; HMGCS1 = 3-hydroxyl-3-methylglutaryl-CoA synthase 1; ACSL1 = acyl-CoA synthetase long-chain; CPT1A = carnitine palmitoyltransferase 1A; CPT2 = carnitine palmitoyltransferase 2; CS = citrate synthase; HMGCS2 = 3-hydroxyl-3-methylglutaryl-CoA synthase 2.

${ }^{2}$ for $=$ forward; rev $=$ reverse. 
tion. Eight microliters of master mix and $2 \mu \mathrm{L}$ of sample volume, containing $20 \mathrm{ng}$ of cDNA, were used. A 3-step PCR program was performed with (1) denaturation for 10 min at $95^{\circ} \mathrm{C}$, (2) 40 cycles of amplification (each consisting of $15 \mathrm{~s}$ at $95^{\circ} \mathrm{C}$, the primer-specific annealing temperature for 30 s; Pfaffl et al., 2002; Graber et al., 2010) and extension at $72^{\circ} \mathrm{C}$ for $20 \mathrm{~s}$ and quantification of fluorescence, and (3) a melting curve program $\left(60-95^{\circ} \mathrm{C}\right)$. The mRNA levels were calculated relative to the mean expression level of the housekeeping genes GAPDH and ubiquitin, which were stable across time points as described by Kreipe et al. (2011).

\section{Statistical Analysis}

Prior to data analysis, the change $(\Delta)$ for each variable (gene expression, plasma metabolites, feed intake, milk yield, and ECM) was calculated by subtracting the value measured after the infusion treatments from the value measured before the infusion treatments. The $\Delta$ for each variable (difference between before and after 48-h infusion) was statistically evaluated using the general linear models procedure of SAS (SAS Institute Inc., Cary, NC, 2002-2008, Release 9.2), including treatment (BHBA or $\mathrm{NaCl}$ ) as fixed effect. Differences between means were determined by the Tukey test. In addition, means of $\Delta$ values obtained within each treatment were tested for their difference from zero. Furthermore, blood plasma variables and the area under the curve was calculated for $\mathrm{d} 2$ of the treatments and subsequently assessed statistically with the model as described above. Data obtained before the treatment were included as covariates in the model to compensate for initial differences between individuals. Data are presented as means \pm SEM, and differences were considered significant if $P<0.05$ and as a trend if $P<0.10$.

\section{RESULTS}

\section{Infusion Rates and Plasma Concentrations of BHBA}

The mean infusion rate of BHBA over $48 \mathrm{~h}$ was 8.5 $\pm 0.6 \mu \mathrm{mol} / \mathrm{kg}$ per min (Figure 1). The mean plasma BHBA concentration reached and maintained was 1.7 $\pm 0.1 \mathrm{mmol} / \mathrm{L}$ for $48 \mathrm{~h}$. The infusion of BHBA resulted in a marked increase in plasma BHBA concentration in HyperB cows $(P<0.001)$. Plasma BHBA concentration in control cows remained unchanged. Consequently, larger are under the curve was observed (Table 2) for plasma BHBA concentration in HyperB $(1.74 \pm 0.02$ $\mathrm{mmol} / \mathrm{L})$ cows compared with the control cows $(0.59 \pm$ $0.02 \mathrm{mmol} / \mathrm{L})$ on d $2(P<0.001)$.

\section{Feed Intake, Energy Balance, and ECM}

Dry matter intake of hay and concentrate before the infusions ( $\mathrm{d} 0$ ) is shown in Table 3 . On $\mathrm{d} 1$ of the infusions, DMI of hay and concentrate was $19.1 \pm$ 0.4 and $16.9 \pm 1.9 \mathrm{~kg} / \mathrm{d}$ for HyperB and control cows, respectively. On d 2 of the infusions, DMI of hay and concentrate was $19.0 \pm 0.9$ and $17.9 \pm 1.0 \mathrm{~kg} / \mathrm{d}$ for HyperB and control cows, respectively. The DMI was not affected by BHBA infusion.

The nutritive energy balance was not affected by BHBA infusion and was similar in both groups across the study period. The $\Delta$ from d 0 to d 2 was $-1.04 \pm$ 8.67 and $1.72 \pm 4.9 \mathrm{MJ} / \mathrm{d}$ for HyperB and control cows, respectively. Milk yield and ECM were not affected by BHBA infusion.

\section{Blood Metabolites and Enzymes}

Plasma glucose concentration in HyperB cows decreased $(P=0.03$; Table 4$)$ and was lower compared with control group on d $2(P=0.0012$; Table 2 and Figure 2). $\beta$-Hydroxybutyrate infusion decreased the plasma glucagon concentration on d $2(P=0.03$; Figure 3). Plasma concentrations of NEFA, IGF-1, urea, triglyceride, cortisol, and insulin (Figure 4) remained unchanged in both HyperB and control groups during the course of infusion. The plasma urea, IGF-1, and triglycerides decreased within control group, and the plasma glucose and urea decreased within HyperB group.

\section{Liver Gene Expression}

The mRNA abundance in liver of the studied variables did not differ between treatments (Table 5). $\beta$-Hydroxybutyrate infusion affected abundance of PRKAA1on mRNA and tended to be lower in the HyperB group than the control group $(P=0.08)$. The mRNA abundance of PC increase and that of pyruvate dehydrogenase (lipomide) $\alpha 1$, and HMGCS1 decreased $(P<0.05)$ over time within the control cows. In the HyperB group, the mRNA abundance of HMGCS1 decreased significantly over time.

\section{DISCUSSION}

The objective was to induce an elevated plasma concentration of BHBA, without the metabolic situation as observed during the early lactation, to solely investigate the effect of BHBA on feed intake, milk yield, and metabolism. To the best of our knowledge, this study is the first that has induced an elevated plasma 
Table 2. Least squares means \pm SEM of area under the curve for plasma variables concentration in dairy cows infused with BHBA (HyperB) or saline $(\mathrm{NaCl})$ on $\mathrm{d} 2$

\begin{tabular}{|c|c|c|c|}
\hline Variable & Group & $\mathrm{LSM} \pm \mathrm{SEM} \mathrm{d} 2$ & $\begin{array}{c}\text { ANOVA } \\
(P \text {-value, group) }\end{array}$ \\
\hline Glucose $(\mathrm{mmol} / \mathrm{L})$ & $\begin{array}{l}\text { HyperB } \\
\mathrm{NaCl}\end{array}$ & $\begin{array}{l}3.47 \pm 0.11 \\
4.11 \pm 0.08\end{array}$ & $<0.01$ \\
\hline Insulin $(\mathrm{mU} / \mathrm{L})$ & $\begin{array}{l}\text { HyperB } \\
\mathrm{NaCl}\end{array}$ & $\begin{array}{l}12.7 \pm 1.4 \\
13.9 \pm 1.1\end{array}$ & 0.54 \\
\hline $\mathrm{BHBA}(\mathrm{mmol} / \mathrm{L})$ & $\begin{array}{l}\text { HyperB } \\
\mathrm{NaCl}\end{array}$ & $\begin{array}{l}1.74 \pm 0.02 \\
0.59 \pm 0.02\end{array}$ & $<0.001$ \\
\hline NEFA (mmol/L) & $\begin{array}{l}\text { HyperB } \\
\mathrm{NaCl}\end{array}$ & $\begin{array}{l}0.06 \pm 0.03 \\
0.09 \pm 0.02\end{array}$ & 0.51 \\
\hline Urea $(\mathrm{mmol} / \mathrm{L})$ & $\begin{array}{l}\text { HyperB } \\
\mathrm{NaCl}\end{array}$ & $\begin{array}{l}3.77 \pm 0.31 \\
3.97 \pm 0.24\end{array}$ & 0.63 \\
\hline Glucagon $(\mathrm{pg} / \mathrm{mL})$ & $\begin{array}{l}\text { HyperB } \\
\mathrm{NaCl}\end{array}$ & $\begin{array}{r}97.4 \pm 3.3 \\
107.7 \pm 2.6\end{array}$ & $<0.05$ \\
\hline IGF-1 (ng/mL) & $\begin{array}{l}\text { HyperB } \\
\mathrm{NaCl}\end{array}$ & $\begin{array}{l}90 \pm 4.5 \\
80 \pm 3.6\end{array}$ & 0.11 \\
\hline Triglycerides $(\mathrm{mmol} / \mathrm{L})$ & $\begin{array}{l}\text { HyperB } \\
\mathrm{NaCl}\end{array}$ & $\begin{array}{l}0.15 \pm 0.01 \\
0.14 \pm 0.01\end{array}$ & 0.58 \\
\hline Cortisol (ng/mL) & $\begin{array}{l}\text { HyperB } \\
\mathrm{NaCl}\end{array}$ & $\begin{array}{l}2.41 \pm 0.55 \\
2.62 \pm 0.43\end{array}$ & 0.78 \\
\hline
\end{tabular}

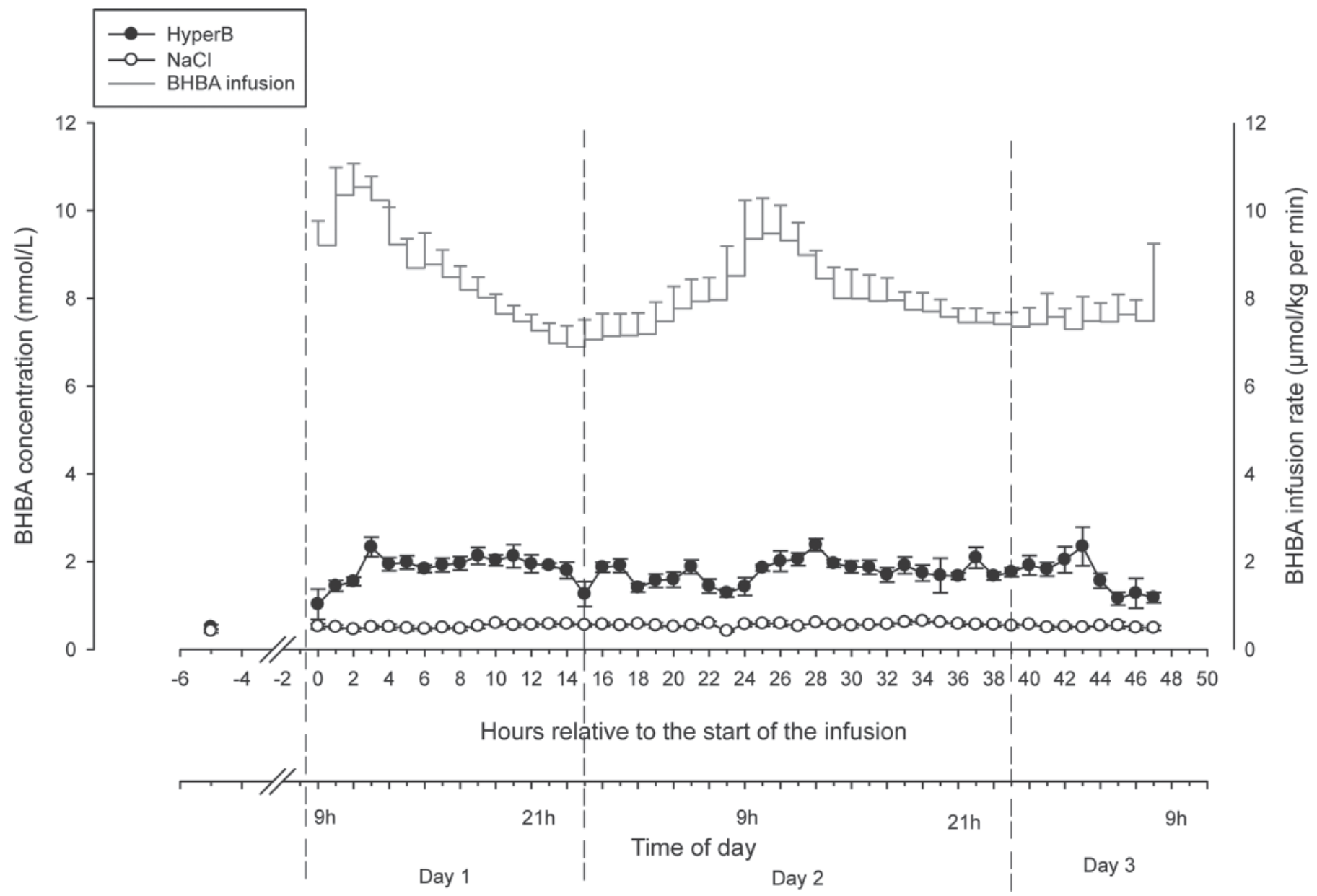

Figure 1. $\beta$-Hydroxybutyrate infusion rate during 48-h infusion in BHBA cows (HyperB). Plasma BHBA concentration in control cows and cows infused with BHBA before the start of the infusion (d 0) and during 48-h infusion. Values represent mean \pm SEM. 
Table 3. Milk yield, ECM, DMI, and energy balance (EB) of dairy cows infused with BHBA (HyperB) or saline $(\mathrm{NaCl})$ before the start of the infusion (d 0$)$ and difference $(\Delta \mathrm{d} 2-\mathrm{d} 0)$ between before and after $48-\mathrm{h}$ infusion (d 2); values represent mean \pm SEM

\begin{tabular}{llccc}
\hline Variable & Group & d 0 & $\Delta$ d 2-d 0 & $\begin{array}{c}\text { ANOVA } \\
(P \text {-value, group })\end{array}$ \\
\hline Milk yield $(\mathrm{kg} / \mathrm{d})$ & HyperB & $23.31 \pm 0.78$ & $-3.30 \pm 1.43^{*}$ & 0.3 \\
& NaCl & $21.78 \pm 2.53$ & $-1.76 \pm 0.68$ & \\
ECM $(\mathrm{kg} / \mathrm{d})$ & HyperB & $21.00 \pm 0.28$ & $-1.58 \pm 0.76$ & 0.79 \\
& NaCl & $21.95 \pm 2.58$ & $-1.21 \pm 0.85$ & \\
DMI $(\mathrm{kg} /$ day $)$ & HyperB & $19.82 \pm 0.66$ & $-0.80 \pm 1.22$ & 0.76 \\
EB $(\mathrm{MJ} / \mathrm{d})$ & NaCl & $18.33 \pm 1.28$ & $-0.38 \pm 0.76$ & \multirow{2}{*}{0.77} \\
& HyperB & $15.04 \pm 2.18$ & $-1.04 \pm 8.67$ & \\
\hline
\end{tabular}

*Delta is different from $0(P<0.05)$.

BHBA concentration for $48 \mathrm{~h}$ in dairy cows by infusion of BHBA. The plasma BHBA concentration reached was $1.7 \pm 0.1 \mathrm{mmol} / \mathrm{L}$, which was clearly above the considered concentration of 1.2 to $1.4 \mathrm{mmol} / \mathrm{L}$ referring to subclinical ketosis (Duffield et al., 2009; Ospina et al., 2010).

The expected reduction of DMI in HyperB cows, as shown in cows with spontaneously elevated ketone body concentrations (Bareille et al., 2003; González et al., 2008), was not observed in our study. Subcutaneous injection of BHBA $(10 \mathrm{mmol} / \mathrm{kg}$ of $\mathrm{BW})$ in rats (Moor et al., 1976; Langhans et al., 1983), intraperitoneal BHBA infusion $\left(15 \mathrm{mmol} / \mathrm{kg}^{0.75}\right)$ in pigmy goats (Rossi et al., 2000), and intracerebroventricular BHBA infusion $(18 \mathrm{~m} M / \mathrm{d})$ in dairy cows (Kuhla et al., 2011) decreased feed intake. $\beta$-Hydroxybutyrate can play a role in the regulation of feed intake (Langhans et al., 1983). In an in vitro experiment, elevation of the
BHBA to glucose ratio to $1: 1$ in early lactation, compared to nonketotic cows with a 1:4 ratio, can decrease feed intake via stimulation of dephosphorylation of $5^{\prime}$ adenosine monophosphate-activated protein kinase (AMPK) after parturition (Laeger et al., 2012). In the current study, BHBA infusion did not affect feed intake throughout the experiment, which may relate to a low ratio of BHBA to glucose.

During the experiment plasma glucose concentration decreased dramatically due to the infusion of BHBA. This finding is consistent with other reports of decreased plasma glucose concentration associated with elevated BHBA in pregnant sheep (Schlumbohm and Harmeyer 2003, 2004), dogs (Felts et al., 1964; Madison et al., 1964), and pigs (Müller et al., 1984). However, our findings are in contrast to other reports that described a hyperglycemia in rabbits (Mirsky and Broh- Kahn, 1937) induced by ketone bodies infusion.

Table 4. Plasma variables concentrations in dairy cows infused with BHBA (HyperB) or saline (NaCl) before the start of the infusion ( $\mathrm{d} 0)$ and difference $(\Delta \mathrm{d} 2-\mathrm{d} 0)$ between before and after $48-\mathrm{h}$ infusion (d 2); values represent mean \pm SEM

\begin{tabular}{|c|c|c|c|c|}
\hline Variable & Group & d 0 & $\Delta \mathrm{d} 2-\mathrm{d} 0$ & $\begin{array}{c}\text { ANOVA } \\
(P \text {-value, group })\end{array}$ \\
\hline \multirow[t]{2}{*}{ Glucose $(\mathrm{mmol} / \mathrm{L})$} & HyperB & $4.10 \pm 0.08$ & $-0.46 \pm 0.18^{*}$ & $<0.05$ \\
\hline & $\mathrm{NaCl}$ & $3.87 \pm 0.08$ & $0.10 \pm 0.14$ & \\
\hline \multirow[t]{2}{*}{ Insulin $(\mathrm{mU} / \mathrm{L})$} & HyperB & $8.74 \pm 0.78$ & $-1.56 \pm 0.92$ & 0.30 \\
\hline & $\mathrm{NaCl}$ & $6.78 \pm 1.62$ & $0.14 \pm 1.08$ & \\
\hline \multirow[t]{2}{*}{ BHBA (mmol/L) } & HyperB & $0.51 \pm 0.05$ & $0.74 \pm 0.15^{*}$ & $<0.001$ \\
\hline & $\mathrm{NaCl}$ & $0.42 \pm 0.04$ & $0.09 \pm 0.05$ & \\
\hline \multirow[t]{2}{*}{ NEFA $(\mathrm{mmol} / \mathrm{L})$} & HyperB & $0.11 \pm 0.02$ & $-0.02 \pm 0.02$ & 0.7 \\
\hline & $\mathrm{NaCl}$ & $0.16 \pm 0.03$ & $-0.04 \pm 0.04$ & \\
\hline \multirow[t]{2}{*}{ Urea $(\mathrm{mmol} / \mathrm{L})$} & HyperB & $4.73 \pm 0.34$ & $-1.25 \pm 0.3^{*}$ & 0.73 \\
\hline & $\mathrm{NaCl}$ & $5.0 \pm 0.26$ & $-1.05 \pm 0.4^{*}$ & \\
\hline \multirow{2}{*}{ IGF-1 (ng/mL) } & HyperB & $91 \pm 6.1$ & $-6.65 \pm 2.5$ & 0.55 \\
\hline & $\mathrm{NaCl}$ & $100 \pm 10.0$ & $-9.87 \pm 3.7^{*}$ & \\
\hline \multirow[t]{2}{*}{ Glucagon $(\mathrm{pg} / \mathrm{mL})$} & HyperB & $115.2 \pm 19.1$ & $-17.3 \pm 1.3^{*}$ & 0.06 \\
\hline & $\mathrm{NaCl}$ & $109.6 \pm 5.4$ & $-1.0 \pm 6.1$ & \\
\hline \multirow{2}{*}{ Triglycerides $(\mathrm{mmol} / \mathrm{L})$} & HyperB & $0.18 \pm 0.01$ & $-0.02 \pm 0.01$ & 0.91 \\
\hline & $\mathrm{NaCl}$ & $0.16 \pm 0.01$ & $-0.02 \pm 0.01^{*}$ & \\
\hline \multirow[t]{2}{*}{ Cortisol (ng/mL) } & HyperB & $5.74 \pm 1.4$ & $-2.37 \pm 1.9$ & 0.67 \\
\hline & $\mathrm{NaCl}$ & $2.92 \pm 0.8$ & $-1.56 \pm 0.9$ & \\
\hline
\end{tabular}

*Delta is different from $0(P<0.05)$. 


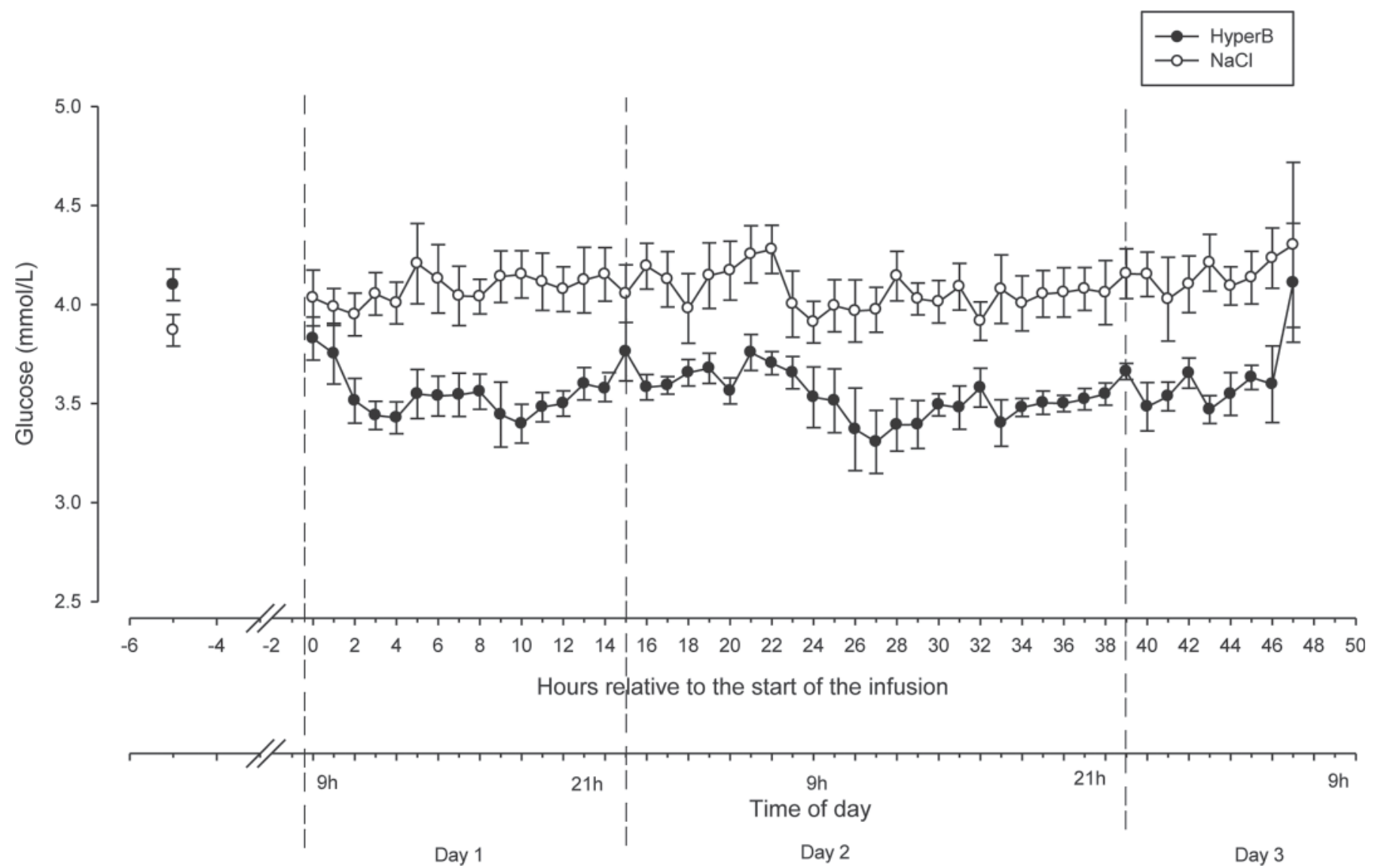

Figure 2. Plasma glucose concentration in control cows and cows infused with BHBA (HyperB) before the start of the infusion (d 0) and during 48 -h infusion. Values represent mean \pm SEM.

Information about the reasons for decreased plasma glucose concentration due to the elevated BHBA concentration is limited; hypothetically, insulin plays a role in this effect. Infusion of BHBA increases insulin secretion in pigs (Müller et al., 1984). Madison et al. (1964) suggested that pancreatic beta cells respond to the high plasma BHBA concentration with increased insulin secretion in dogs. It appears that insulin suppresses the glucose production throughout an inhibitory effect on the regulatory enzymes of gluconeogenesis (Brockman and Larrveld, 1986; Hayirli, 2006). This release of endogenous insulin can lead to a decline in plasma glucose concentration and reduce hepatic glucose production. The unchanged insulin concentration in response to the BHBA infusion in the present study may be explained by the fact that ketone bodies represent only a modest stimulus on insulin secretion in ruminants (Jordan and Philips, 1978; Heitmann and Fernandez, 1986). Insulin obviously did not play a significant role in mediating the lowering effect of BHBA on plasma glucose concentration in sheep (Schlumbohm and Harmeyer, 2003). Decreased glucose concentration and hepatic glucose output due to the infusion of BHBA can reduce the availability of glucose for the peripheral tissues because exhausted glucose stores must be replaced by a catabolism of proteins during emergency conditions for the vital tissues, such as central nervous system (Madison et al., 1964). The molarity of ketone bodies in plasma is the same or higher than that of glucose. Thus, enhanced plasma BHBA concentration can increase the efficiency of BHBA as a competitor to glucose used by peripheral tissues, and has been shown to inhibit peripheral glucose utilization (Madison et al., 1964). Glucose is required as a unique source for mammary lactose synthesis or energy for red blood cells. However, during limited glucose availability in the body, extra hepatic tissues (e.g., brain) can use ketone bodies as an alternative fuel, and ketone bodies have a glucosesparing effect in the tissues where they can be used as energy source. Mebane and Madison (1962) demonstrated that ketone body infusion leads to a $30 \%$ reduction in glucose utilization by peripheral tissues. Previous studies also reported that the oxidation of glucose was inhibited by ketone body infusion (Neptune 


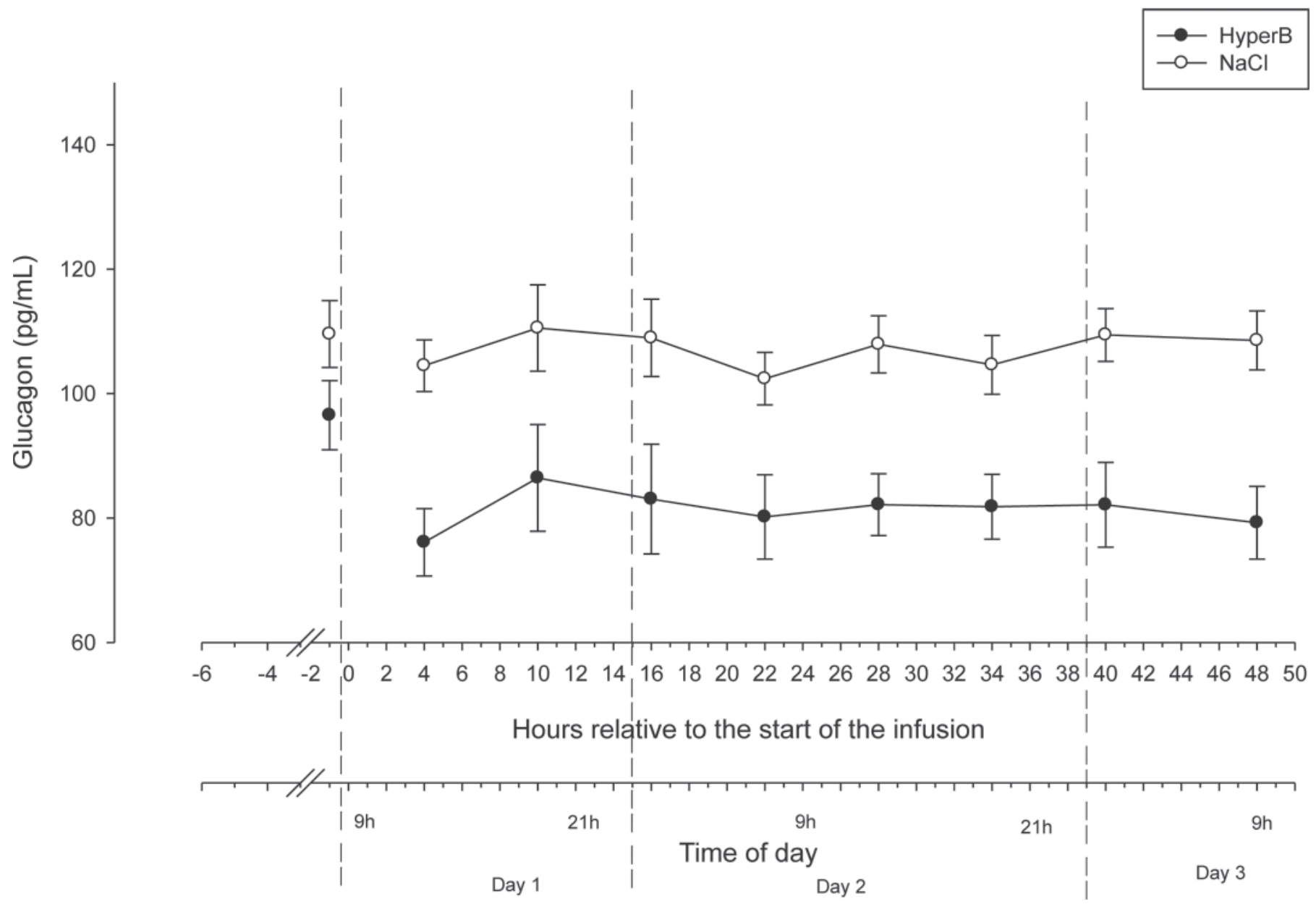

Figure 3. Plasma glucagon concentration in control cows and cows infused with BHBA (HyperB) before the start of the infusion (d 0) and during 48-h infusion. Values represent mean \pm SEM.

et al., 1961; Williamson and Krebs, 1961). In contrast, as mentioned previously, Schlumbohm and Harmeyer (2004) suggested that BHBA infusion decreased endogenous glucose production but did not affect glucose utilization in pregnant sheep. Furthermore, they suggested that the elevated concentration of ketone bodies in blood initially decreases glucose production via the depressed signal on hepatic gluconeogenesis in liver.

In contrast to a previous study that found increased glucagon concentrations after BHBA infusion in pigs (Müller et al., 1984), in the current study BHBA infusion decreased glucagon concentration in HyperB compared with the control group. Plasma glucose is derived from the feed, glycogen, and by gluconeogenesis, and it is regulated by several hormones, mainly glucagon and insulin. Glucagon increases plasma glucose concentration through stimulation of gluconeogenesis and glycogenolysis (Aronoff et al., 2004; Taborsky, 2010). Changes in glucagon secretion from the physiological range results in changes of plasma glucose concentra- tion (Taborsky, 2010); some substrates, such as NEFA and ketone bodies, suppress glucagon secretion (Gerich et al., 1974;1976; Goberna et al., 1974). Evidence exists that glucagon secretion is inhibited by the neighboring beta cell through insulin (Weir et al., 1976) and $\gamma$-aminobutyric acid (GABA; Adeghate et al., 2000; Wendt et al., 2004). $\gamma$-Aminobutyric acid is an inhibitory neurotransmitter in the brain. In an in vitro study it was demonstrated that BHBA increases GABA concentration in the epileptic brain (Suzuki et al., 2009). Therefore, it can be hypothesized that the decrease in glucagon concentration in the current study is related to elevated BHBA concentration - as BHBA is used as an alternative fuel and energy source for the tissuesor glucagon secretion was inhibited by GABA, whose concentration likely increased during elevated BHBA. Subsequently, a decline of glucagon secretion decreased glucose production through the effect on glycogenolysis or gluconeogenesis during the experiment. A decrease of plasma NEFA concentration was expected in response 


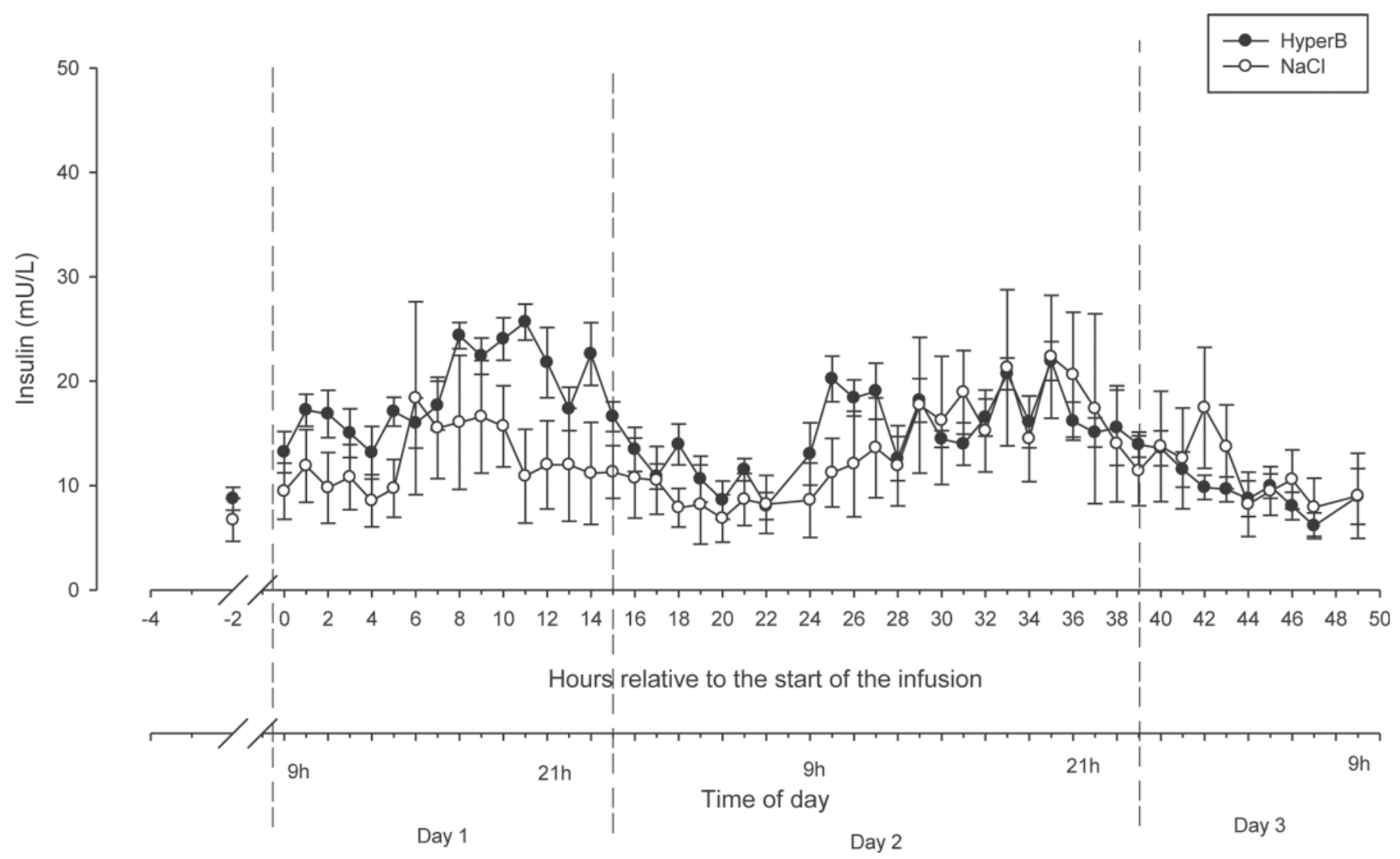

Figure 4. Plasma insulin concentration in control cows and cows infused with BHBA (HyperB) before the start of the infusion (d 0) and during 48-h infusion. Values represent mean \pm SEM.

to the BHBA infusion and a subsequent increase of insulin (Madison et al., 1964); however, both variables did not change during the experimental period.

$\beta$-Hydroxybutyrate can replace glucose to be utilized in peripheral tissues (Madison et al., 1964), which can also potentially contribute to reduced FA mobilization from adipose tissues. Conversely, after a decline in glucose during negative energy balance, NEFA plasma concentration increased in early lactation (van Dorland et al., 2009). The main difference of the current study from the previous one is the absence of negative energy balance despite decreased glucose, with the respective differences of insulin secretion. However, as the main site of ketone body synthesis from fatty acid oxidation, the liver cannot utilize ketone bodies for the synthesis of acetoacetyl CoA, and subsequently FA, due to a lack of succinyl-CoA:3-ketoacid-coenzyme A transferase 1, mitochondrial (Goodridge and Sul, 2000).

\section{Effects of BHBA Infusion on Hepatic Gene Expression}

The present results of mRNA abundance of key enzymes related to hepatic gluconeogenesis (PC, glucose- 6-phosphatase, mitochondrial phosphoenolpyruvate carboxykinase) are in contrast with suggestions from previous studies that indicated an inhibition of gluconeogenesis by elevated plasma BHBA concentration (Müller et al., 1984; Schlumbohm and Harmeyer, 2003). Müller et al. (1984) suggested that ketone bodies probably have a direct inhibitory action on gluconeogenesis. They mentioned that the effect of ketone bodies on endogenous glucose production is probably mediated by insulin. However, in ruminants, the effect of ketone bodies on insulin secretion is not strong (Jordan and Philips, 1978; Heitmann and Fernandez, 1986), and insulin concentration did not change in the current study. Soling and Kleineke (1976) suggested that ketone bodies have a glucose-sparing effect in tissues through the mitochondrial formation of citrate, an allosteric inhibitor, phosphofructo-1,6-kinase, acetyl-CoA inhibition of pyruvate dehydrogenase and activation of PC. $\beta$-Hydroxybutyrate infusion did not affect key enzymes related to gluconeogenesis, glycolysis, pyruvate dehydrogenase complex, and citrate synthase mRNA expression. According to the mRNA abundance of some enzymes related to FA oxidation, BHBA infusion did 
Table 5. Liver mRNA expression in dairy cows infused with BHBA (HyperB) or saline ( $\mathrm{NaCl}$ ) before the start of the infusion (d 0) and difference $(\Delta \mathrm{d} 2-\mathrm{d} 0)$ between before and after 48-h infusion (d 2); values represent mean \pm SEM

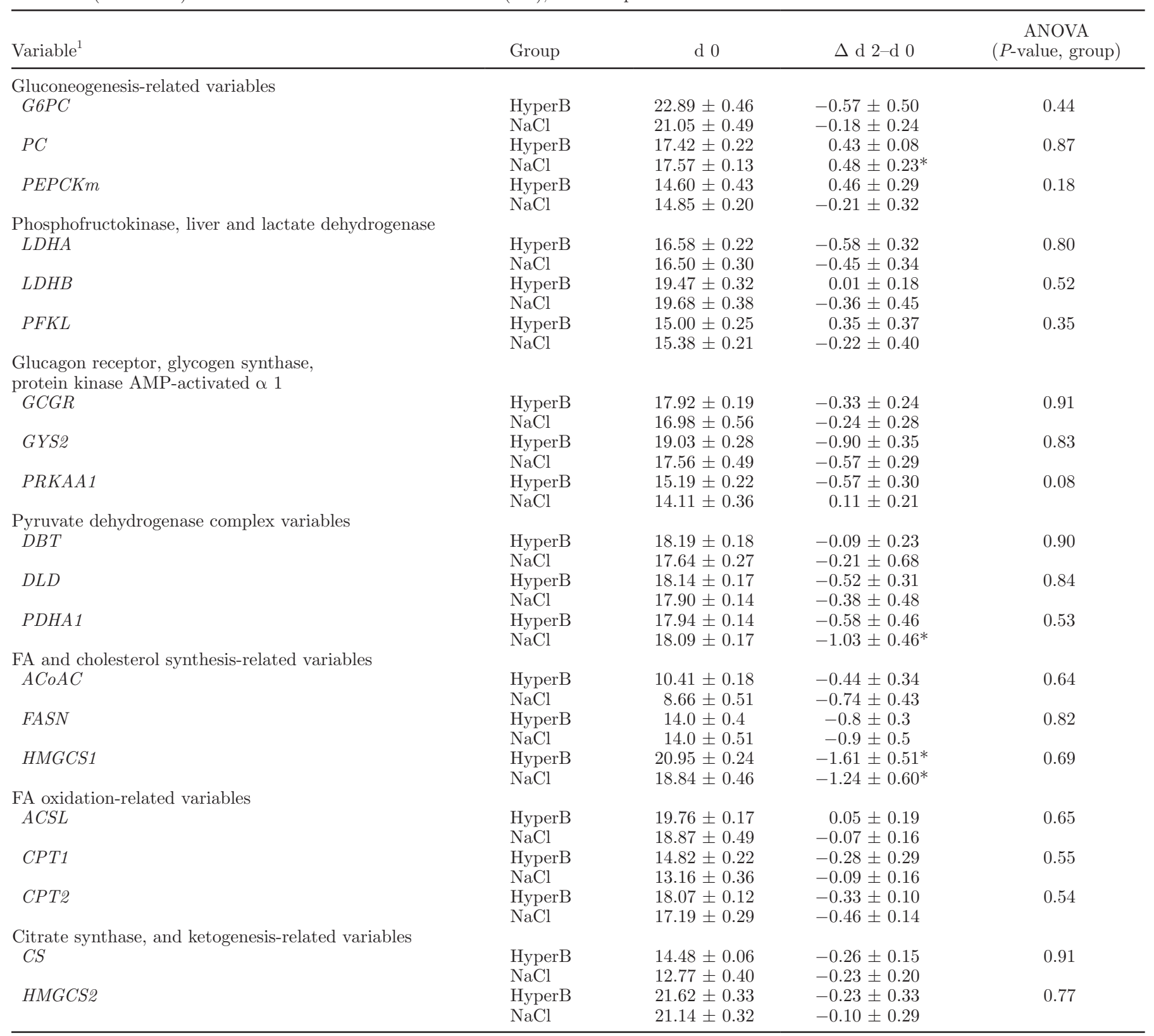

${ }^{1} \mathrm{G} 6 \mathrm{PC}=$ glucose-6-phosphatase $\mathrm{PC}=$ pyruvate carboxylase; $\mathrm{PEPCKm}=$ mitochondrial phosphoenolpyruvate carboxykinase; LDHA $=$ lactate dehydrogenase A; LDHB = lactate dehydrogenase B; PFKL = phosphofructokinase liver; GCGR = glucagon receptor; GYS2 = glycogen synthase 2; PPKA1 = protein kinase AMP-activated $\alpha 1 ; \mathrm{DBT}=$ dihydrolipoamide branched chain transacylase $\mathrm{E} 2 ; \mathrm{DLD}=$ dihydrolipoamide dehydrogenase; PDHA1 = pyruvatedehydrogenase (lipomide) $\alpha 1 ;$ ACoAC $=$ acetyl-CoA carboxylase; FASN = fatty acid synthase; HMGCS1 = 3-hydroxyl-3 - methylglutaryl-CoA synthase 1; ACSL1 = acyl-CoA synthetase long-chain; CPT1A = carnitine palmitoyltransferase 1A; CPT2 $=$ carnitine palmitoyltransferase $2 ; \mathrm{CS}=$ citrate synthase; HMGCS2 $=3$-hydroxyl-3-methylglutaryl-CoA synthase 2.

*Delta is different from $0(P<0.05)$.

not affect FA oxidation. These results are not in agreement with previous reports (Soling and Kleineke, 1976; Morio and Wolfe, 2005) that mentioned ketone bodies are an inhibitor for FA oxidation through increase acetyl CoA production, inhibit carnitine palmitoyltransferase activity, and stimulate malonyl CoA synthesis.
As mentioned previously, ketone bodies suppressed the glucagon secretion, and this inhibition could have been regulated via cyclic AMP. The mechanism of this inhibition is related to the generation of ATP or ADP by substrate, such as ketone bodies, then decrease of cAMP, and finally prevention of glucagon secretion 
(Toyota et al., 1975; Gerich et al., 1976; Mitrakou et al., 1991; Adeghate et al., 2000). In the present study, the PRKAA1 expression tended to decrease in HyperB compared with control group $(P<0.1)$. Conversely, BHBA infusion decreased the PRKAA1 expression, and subsequently glucagon excretion was decreased.

\section{CONCLUSIONS}

Results from this study demonstrate that intravenous BHBA infusion successfully induced elevated plasma BHBA concentration over $48 \mathrm{~h}$ in dairy cows. Feed intake was not affected by elevated BHBA concentration during a period when energy balance is positive. Decreased plasma glucose concentration during BHBA administration cannot be related to changes of insulin concentration or to mRNA abundance of genes related to hepatic gluconeogenesis, FA synthesis, citrate synthase, pyruvate dehydrogenase complex, and glycolysis. Although mRNA expression indicated high activity of enzyme production, the effects of BHBA infusion most likely occurred at a posttranscriptional level. Reduced glucose concentration may be related to a decrease in plasma glucagon concentration, which can decrease glucose production from gluconeogenesis or glycogen storage. Thus, BHBA seems to have a glucose-sparing effect. However, glucose entry rate was probably reduced by the treatment, and additional studies will be necessary to clarify the underlying mechanisms.

\section{ACKNOWLEDGMENTS}

This study was supported by a grant of the Swiss National Science Foundation (Bern, Switzerland; grant no. 320030-120317). We thank Yolande Zbinden, Claudine Morel, and Chantal Philipona (Veterinary Physiology, Vetsuisse Faculty, University of Bern, Switzerland) for their support in the laboratory analyses.

\section{REFERENCES}

Adeghate, E., A. S. Ponery, D. J. Pallot, and J. Singh. 2000. Distribution of neurotransmitters and their effects on glucagon secretion from the in vitro normal and diabetic pancreatic tissues. Tissue Cell 32:266-274.

Agenäs, S., E. Burstedt, and K. Holtenius. 2003. Effect of feeding intensity during the dry period. 1. Feed intake, body weight, and milk production. J. Dairy Sci. 86:870-882.

Aronoff, S. L., K. Berkowitz, B. Shreiner, and L. Want. 2004. Glucose metabolism and regulation: Beyond insulin and glucagon. Diabetes Spectrum 17:183-190.

Bareille, N., F. Beaudeau, S. Billon, A. Robert, and P. Faverdin. 2003. Effects of health disorders on feed intake and milk production in dairy cows. Livest. Prod. Sci. 83:53-62.

Bergman, E. N. 1971. Hyperketonemia- ketogenesis and ketone body metabolism. J. Dairy Sci. 54:936-948.
Blum, J. W., F. Jans, W. Moses, D. Fröhli, M. Zemp, M. Wanner, I. C. Hart, R. Thun, and U. Keller. 1985. Twenty-four-hour pattern of blood hormone and metabolite concentrations in high-yielding dairy cows: Effects of feeding low or high amounts of starch, or crystalline fat. Zbl. Vet. Med. A 32:401-418.

Brockman, R. P., and B. Larrveld. 1986. Effect of insulin on gluconeogenesis and the metabolism of lactate in sheep. Can. J. Physiol. Pharmacol. 64:1055-1059.

Duffield, T. F. 2000. Subclinical ketosis in lactating dairy cattle. Pages 231-253 in Metabolic Disorder of Ruminants. The Veterinary Clinic of North America. Vol. 16 No. 2. July.

Duffield, T. F., K. D. Lissemore, B. W. McBride, and K. E. Lesli. 2009. Impact of hyperketonemia in early lactation dairy cows on health and production. J. Dairy Sci. 92:571-580.

Felts, P. W., O. B. Crofford, and C. R. Park. 1964. Effect of infused ketone bodies on glucose utilization in dog. J. Clin. Invest. 43:638646.

Gerich, J. E., M. A. Charles, and G. M. Grodsky. 1974. Characterization of the effects of arginine and glucose on glucagon and insulin release from the perfused rat pancreas. J. Clin. Invest. 54:833841

Gerich, J. E., M. A. Charles, and G. M. Grodsky. 1976. Regulation of pancreatic insulin and glucagon secretion. Annu. Rev. Physiol. 38:353-388.

Goberna, R., J. Jr. Tamarit, J. Osorio, R. Fussganger, J. Tamarit, and E. F. Pfeiffer. 1974. Action of B-hydroxy butyrate, acetoacetate and palmitate on the insulin release in the perfused isolated rat pancreas. Horm. Metab. Res. 6:256-260.

González, L. A., B. J. Tolkamp, M. P. Coffey, A. Ferret, and I. Kyriazakis. 2008. Changes in feeding behavior as possible indicators for the automatic monitoring of health disorders in dairy cows. J. Dairy Sci. 91:1017-1028.

Goodridge, A. G., and H. S. Sul. 2000. Lipid metabolism-Synthesis and oxidation. Pages 305-350 in Biochemical and Physiological Aspects of Human Nutrition. Stipanuk, M. H. ed. W.B. Saunders Company, Philadelphia, PA.

Graber, M., S. Kohler, T. Kaufmann, M. G. Doherr, R. M. Bruckmaier, and H. A. van Dorland. 2010. A field study on characteristics and diversity of gene expression in the liver of dairy cows during the transition period. J. Dairy Sci. 93:5200-5215.

Gross, J., H. A. van Dorland, R. M. Bruckmaier, and F. J. Schwarz. 2011. Performance and metabolic profile of dairy cows during a lactational and deliberately induced negative energy balance with subsequent realimentation. J. Dairy Sci. 94:1820-1830.

Hammon, H. M., S. N. Sauter, M. Reist, Y. Zbinden, C. Philipona, C. Morel, and J. W. Blum. 2003. Dexamethasone and colostrums feeding affect hepatic gluconeogenic enzymes differently in neonatal calves. J. Anim. Sci. 81:3095-3106.

Hayirli, A. 2006. The role of exogenous insulin in the complex of hepatic lipidosis and ketosis associated with insulin resistance phenomenon in postpartum dairy cattle. Vet. Res. Commun. 30:749-774.

Heitmann, R. N., and J. M. Fernandez. 1986. Autoregulation of alimentary and hepatic ketogenesis in sheep. J. Dairy Sci. 69:12701281.

Herdt, T. H. 2000. Ruminant adaptation to negative energy balance. Vet. Clin. North Am. Food Anim. Pract. 16:215-230.

Jordan, H. N., and R. W. Philips. 1978. Effect of fatty acid on isolated ovine pancreatic islet. Am. J. Physiol. 234:E162-E167.

Kreipe, L., M. C. M. B. Vernay, A. Oppliger, O. Wellnitz, R. M. Bruckmaier, and H. A. van Dorland. 2011. Induced hypoglycemia for 48 hours indicates differential glucose and insulin effects on liver metabolism in dairy cows. J. Dairy Sci. 94:5435-5448.

Kuhla, B., M. Derno, R. Pöhland, C. C. Metges, and T. Laeger. 2011. Central administration of Beta-hydroxybutyrate inhibits feed intake in dairy cows and reduces Agrp expression via AMP-activated protein kinase signaling. Page 84 in Int. Oskar Kellner Symp. Leibniz-Institut für Nutztierbiologie, Dummerstorf, Germany.

Laeger, T., H. M. Hammon, and B. Kuhla. 2012. Beta-hydroxybutyric acid/glucose ratio dependnt orexigenic signaling in hypothalamic GT1-7 cells. Proc. Soc. Nutr. Physiol. 21:52. 
Laffel, L. 1999. Ketone bodies: A review of physiology, patophysiology and application of monitoring to diabetes. Diabetes Metab. Res. Rev. 15:412-426.

Langhans, W., F. Wiesenreiter, and E. Scharrer. 1983. Different effects of subcutaneous D,L-3-hydroxybutyrate and acetoacetate injection on food intake in rats. Physiol. Behav. 31:483-486.

Madison, L. L., D. Mebane, H. R. Unger, and A. Lochner. 1964. The hypoglycemic action of ketones. II. Evidence for a stimulatory feedback of ketones on the pancreatic beta cells. J. Clin. Invest. 43:408-415.

Mebane, D., and L. L. Madison. 1962. The hypoglycemic effect of ketone bodies. J. Clin. Invest. 41:1383. (Abstr.)

Mirsky, I. A., and R. H. Broh-Kahn. 1937. The influence of increased metabolism on $\beta$-hydroxybutyric acid utilization. Am. J. Physiol. 120:446.

Mitrakou, A., C. Ryan, T. Veneman, M. Mokan, T. Jenssen, I. Kiss, J. Durrant, P. Cryer, and J. Gerich. 1991. Hierarchy of glycemic thresholds for counterregulatory hormone secretion, symptoms, and cerebral dysfunction. Am. J. Physiol. 260:E67-E74.

Moore, T. J., A. P. Lione, M. C. Sugden, and D. M. Regen. 1976. Beta-hydroxybutyrate transport in rat brain: Developmental and dietary modulations. Am. J. Physiol. 230:619-630.

Morio, B., and R. R. Wolfe. 2005. Ketone bodies. eLS http://dx.doi. org/10.1038/npg.els.0003819.

Müller, M. J., U. Paschen, and H. J. Seitz. 1984. Effect of ketone bodies on glucose production and utilization in the miniature pig. J. Clin. Invest. 74:249-261.

Neptune, E. M., H. C. Sudduth, F. J. Fash, and J. J. Reish. 1961. Metabolism of beta-hydroxybutyrate and acetoacetate. Am. J. Physiol. 201:235.

Ospina, P. A., D. V. Nydam, T. Stokol, and T. R. Overton. 2010 Evaluation of nonesterified fatty acids and $\beta$-Hydroxybutyrate in transition dairy cattle in the northeastern United States: Critical thresholds for prediction of clinical diseases. J. Dairy Sci. 93:546-554.

Pfaffl, M. W., T. Mircheva Georgieva, I. Penchev Georgiev, E. Ontsouka, M. Hageleit, and J. W. Blum. 2002. Real-time RT-PCR quantification of insulin-like growth factor (IGF)-1, IGF-1 receptor, IGF-2, IGF-2 receptor, insulin receptor, growth hormone receptor, IGF binding proteins 1, 2 and 3 in the bovine species. Domest. Anim. Endocrinol. 22:91-102.

Rossi, R., S. Dorig, E. del Prete, and E. Scharrer. 2000. Suppression of feed intake after parenteral administration of D-beta-hydroxybutyrate in pygmy goats. J. Vet. Med. Ser. A: Physiol. Pathol. Clin. Med. 47:9-16.

Ruderman, N. B., and M. N. Goodman. 1973. Regulation of ketone body metabolism in skeletal muscle. Am. J. Physiol. 224:13911397.

Sandholm, M. 1976. Coagulation of serum by glutaraldehyde. Clin. Biochem. 9:39-41.

Schlumbohm, C., and J. Harmeyer. 2003. Hypocalcemia reduces endogenous glucose production in Hyperketonemic sheep. J. Dairy Sci. 86:1953-1962.
Schlumbohm, C., and J. Harmeyer. 2004. Hyperketonemia impair glucose metabolism in pregnant and nonpregnant ewes. J. Dairy Sci $87: 350-358$

Shaw, J. C. 1943. A comparison of acetone body metabolism of the lactating mammary gland of the normal cow with that of the cow with ketosis. J. Biol. Chem. 142:53.

Sjaunja, L. O., L. Baevre, L. Junkkarinen, J. Pedersen, and J. Setala. 1991. A Nordic proposal for an energy corrected milk (ECM) formula. Pages 156-157 in Performance Recording of Animal State of the Art 1990. P. Gaillon, and Y. Chabert, ed. EAAP Publication 50. Center for Agricultural Publishing and Documentation, Wageningen, the Netherlands.

Soling, H. D., and J. Kleineke. 1976. Species dependent regulation of hepatic gluconeogenesis in higher animals. Pages 369-462 in Gluconeogenesis: Its Regulation in Mammalian Species. R. W. Hanson, and M. A. Mehlman, ed. Wiley, New York, NY.

Suzuki, Y., H. Takahashi, M. Fukuda, H. Hino, K. Kobayashi, J. Tanaka, and E. Ishii. 2009. $\beta$-Hydroxybutyrate alters GABA-transaminase activity in cultured astrocytes. Brain Res. 1268:17-23.

Taborsky, G. J. Jr. 2010. The physiology of glucagon. J. Diabetes Sci. Technol. 4:1338-1344

Toyota, T., S. I. Sato, M. Kudo, K. Abe, and Y. Goto. 1975. Secretory regulation of endocrine pancreas: Cyclic AMP and glucagon secretion. J. Clin. Endocrinol. Metab. 41:81-89.

van Dorland, H. A., S. Richter, I. Morel, M. G. Doherr, N. Castro, and R. M. Bruckmaier. 2009. Variation in hepatic regulation of metabolism during the dry period and in early lactation in dairy cows. J. Dairy Sci. 92:1924-1940.

Veech, R. L. 2004. The therapeutic implication of ketone bodies: The effects of ketone bodies in pathological conditions: Ketosis, ketogenic diet, redox states, insulin resistance, and mitochondrial metabolism. Prostaglandins Leukot. Essent. Fatty Acids 70:309-319.

Vicari, T., J. J. G. C. van den Borne, W. J. J. Gerrits, Y. Zbinden, and J. W. Blum. 2008. Postprandial blood hormone and metabolite concentrations influenced by feeding frequency and feeding level in veal calves. Domest. Anim. Endocrinol. 34:74-88.

Weidemann, M. J., and H. A. Krebs. 1969. The fuel of respiration of rat kidney cortex. Biochem. J. 112:149-166.

Weir, G. C., S. D. Knowlton, R. F. Atkins, F. X. McKennan, and D. B. Martin. 1976. Glucagon secretion from the perfused pancreas of streptozotocin-treated rats. Diabetes 25:275-282.

Wendt, A., B. Birnir, K. Buschard, J. Gromada, A. Salehi, S. Sewing, P. Rorsman, and M. Braun. 2004. Glucose inhibition of glucagon secretion from rat alpha-cells is mediated by GABA released from neighboring beta-cells. Diabetes 53:1038-1045.

Williamson, J. R., and H. A. Krebs. 1961. Acetoacetate as fuel of respiration in the perfused rat heart. Biochem. J. 80:540-547. 